\title{
Expression of pathogenesis related genes in response to salicylic acid, methyl jasmonate and 1-aminocyclopropane-1-carboxylic acid in Malus hupehensis (Pamp.) Rehd
}



\begin{abstract}
Background: Many studies have been done to find out the molecular mechanism of systemic acquired resistance $(\mathrm{SAR})$ in plants in the past several decades. Numbers of researches have been carried out in the model plants such as arabidopsis, tobacco, rice and so on, however, with little work done in woody plants especially in fruit trees such as apple. Components of the pathway of SAR seem to be extremely conserved in the variety of species. Malus hupehensis, which is origin in China, is strong resistance with rootstock. In the study, we attempted to make the expression pattern of pathogenesis related (PR) genes which were downstream components of the SAR pathway in response to salicylic acid(SA), methyl jasmonate(MeJA) and 1-aminocyclopropane-1-carboxylic acid(ACC) in Malus hupehensis.

Findings: In order to analyze the expression pattern, the partial sequence of three PR genes from Malus hupehensis, MhPR1, MhPR5 and MhPR8 was isolated. These three PR genes were induced by SA, MeJA and ACC. However, MhPR1, MhPR5 and MhPR8 performed a distinct pattern of expression in different plant organs. MhPR5 and MhPR8 were basal expression in leaves, stems and roots, and MhPR1 was basal expression only in stems. The expression of MhPR1, MhPR5 and MhPR8 was enhanced during the first $48 \mathrm{~h}$ post-induced with SA, MeJA and ACC.

Conclusions: The results showed that a distinct pattern of expression of PR genes in Malus hupehensis which differed from the previous reports on model plants arabidopsis, tobacco and rice. MhPR1, MhPR5 and MhPR8 were induced by SA, MeJA and ACC, which were regarded as the marker genes in the SAR response in Malus hupehensis. In contrast with herbal plants, there could be specific signal pathway in response to SA, JA and ET for woody plants.
\end{abstract}

\section{Background}

In nature, basal defenses have been evolved by plants against the adverse conditions such as pathogens, insects, and injuries and so on. Plants have been invaded multiple aggressors simultaneously or subsequently, which could affect the principal induced defense response of the host plants [1]. Botanists have acknowledged that the phytohormones salicylic acid (SA), jasmonic acid (JA), and ethylene (ET) play key roles in the signaling network that regulates the induced defense

\footnotetext{
* Correspondence: qscnj@njau.edu.cn; zhangzh@njau.edu.cn ${ }^{1}$ College of Horticulture, Nanjing Agricultural University, 1 Weigang, Nanjing, Jiangsu, China
}

responses in plants [2-6]. Plants have evolved powerful regulatory potential by Cross talk among SA-, JA-, and ET-dependent signaling pathways to effectively and efficiently adapt to the complex hostile situation [6-8]. SA-, JA-, and ET-dependent pathways regulated defense responses and were differentially effective to against specific types of invaders in plants $[9,10]$.

Pathogenesis-related (PR) proteins, which are the downstream components of systemic acquired resistance (SAR) in plants, have been used routinely for the defense status of plants with positive antimicrobial activity. PR-proteins are induced in response to attack by pathogens [11]. Plants are able to coordinate the \\ ()}


expression of specific PR genes in response to attack by relevant pathogens at the molecular level.

Regard of SAR and PR genes, there is plenty of information chiefly related to model plants, such as arabidopsis [12], tomato and tobacco [13,14]. Inductions of $P R 1,5$, and 8 are characteristic of SAR in several herbaceous plants. $P R-8$ is strongly induced in cucumber by SA, but less INA (2, 6-dichloroisonicotinic acid) [15]. However, there was lest of the work done in woody plants especially in fruit trees such as apple. Identified from apple, $P R-2, P R-5$ and $P R-8$ are induced in response to inoculation with the apple pathogen, Erwinia amylovora, but they are not induced in young apple stems by treatment with elicitors of SAR in herbaceous plants [16]. However, little work had been done on the expression pattern of pathogen protein genes in response to SA, MeJA and ET in woody perennials.

Malus hupehensis, which was origin in China, was strong resistance to rootstock. In this study, we assayed the expression of $P R$ genes in Malus hupehensis seedlings tissue following treatment with SA, methyl jasmonate (MeJA) and ET prescursor 1-aminocyclopropane-1carboxylic acid (ACC), including in leaves, stems and roots.

\section{Material and methods}

Plant material and treatment

Malus hupehensis (Pamp.) Rehd. tissue culture seedlings were favored by Yujin Hao professor of Shandong agricultural university and subcultured in Murashige and Skoog (MS) medium supplied with 6-BA $(0.5 \mathrm{mg} / \mathrm{L})$ and $\operatorname{NAA}(0.1 \mathrm{mg} / \mathrm{L})$ cultured under a $16 \mathrm{~h}$-light $\left(25^{\circ} \mathrm{C}\right) / 8 \mathrm{~h}$ dark $\left(25^{\circ} \mathrm{C}\right)$ cycle. Seedlings were rooted in $1 / 2$ MS supplied with $0.1 \mathrm{mg} / \mathrm{L}$ NAA after three weeks. Escherichia coli strain DH5a cells were used for the cloning of the MhPR1, MhPR5, MhPR8 genes and the Mhtubulin was regarded as housekeeping gene in semi-quantitative RTPCR assay.

Malus hupehensis culture seedlings rooted three weeks were sprayed with $0.1 \mathrm{mM}$ salicylic acid (SA) (Sigma), $0.02 \mathrm{mM}$ MeJA (Sigma), $0.01 \mathrm{mM}$ ACC (Sigma) supplied with $0.015 \%$ (v/v) Silwet L77 (Van Meeuwen Chemicals) respectively for 4,12 and $48 \mathrm{~h}$, taking the seedlings without treatments as control. Three seedlings were duplicated for each treat. The leaves, stems and roots were frozen by plunging the excised portions into liquid nitrogen. After that, the tissues were stored at $-70^{\circ} \mathrm{C}$ for further research in future.

\section{Isolation of total RNA and first strand CDNA Synthesis}

Total RNA was isolated as described previously by CAI et al. [17]. Genomic DNA of total RNA was eliminated by treating with RNase-free DNase I (TaKaRa, Code No: D2215) according to the manufacturer's instruction. The total RNA $(1 \mu \mathrm{g})$ was reversely transcribed with the ReverTra Ace qPCR RT Kit for the cDNA synthesis according to the instructions of manufacturer (TOYOBO, Code No.: FSQ-101). First strand cDNA samples were diluted 1:10 with sterile double distill water and stored at $-20^{\circ} \mathrm{C}$ before being used as template in semi-quantitative RT-PCR.

\section{Semi-quantitative RT-PCR Analysis}

Primers (Table 1) were designed based on the known $P R$ genes sequences deposited in GenBank and were used to amplify the putative $P R$ genes and the housekeeping gene tubulin fragments from cDNA of Malus hupehensis were used as an internal standard. The amplicons of PCR for PR-1, PR-5, PR-8 and Tubulin were cloned through PMD18-T vector and sequenced at Shanghai Invitrogen Biotechnology Co., Ltd. The nucleotide sequences were compared with those released in GenBank Accession Nos. using the BLASTn program [18].

Semi-quantitative RT-PCR amplification was carried out on Alpha Unit Block Assembly for DNA Engine Systems (BIO-RAD) with $20 \mu \mathrm{L}$ of reaction solution, containing $1 \mu \mathrm{L}$ of 10 -fold-diluted cDNA, $0.3 \mu \mathrm{L} 10 \mathrm{pM}$ of each primer (invitrogen), $1.6 \mu \mathrm{L}$ dNTP (TaKaRa Code: D4030A), $2 \mu \mathrm{L} 10 \times$ PCR buffer, $1.5 \mu \mathrm{L} \mathrm{MgCl}_{2}$, $0.125 \mu \mathrm{L}$ rTaq enzyme (TaKaRa Code:R10T1 M ), and $13.175 \mu \mathrm{L}$ sterile double distill water. The reaction protocol as the follows: initial denaturation step at $94^{\circ} \mathrm{C}$ for 3 min followed by 35 cycles at $94{ }^{\circ} \mathrm{C}$ for $30 \mathrm{~s}, 57^{\circ} \mathrm{C}$ for all the primer sets for $30 \mathrm{~s}, 72^{\circ} \mathrm{C}$ for $30 \mathrm{~s}$, exception 25 cycles for Mhtubulin, and a final elongation step at $72^{\circ} \mathrm{C}$ for $5 \mathrm{~min} .10 \mu \mathrm{L}$ of PCR products were separated by electrophoresis in 1.5\% agarose gels and visualized under UV light after staining with ethidium bromide.

Table 1 Primers used for semi-quantitative RT-PCR

\begin{tabular}{llll}
\hline name & $\begin{array}{l}\text { Forward Primer Sequence } \\
{\left[\mathbf{5}^{\prime}-\mathbf{3}^{\prime}\right]}\end{array}$ & $\begin{array}{l}\text { Reverse Primer Sequence } \\
{\left[\mathbf{5}^{\prime}-\mathbf{3}^{\prime}\right]}\end{array}$ & Ampicon size \\
\hline PR1 & CCACAAAGAGAACAAACCATTAAC & GACCAACGCCTACTGCTG & 160 \\
PR5 & CATGTCCTCCCACAGAGTAC & ATATAATCCCATTTCGTGCTTATG & 153 \\
PR8 & AGCAGGTTCTATGACAACGG & CGCCATCATCCCTAACACAC & 112 \\
tubulin & AGGATGCTACAGCCGATGAG & GCCGAAGACTGACGAGAATC & 192 \\
\hline
\end{tabular}

The primers were set using the software beacon designer 7.0 and were synthesized at Shanghai Invitrogen Biotechnology Co., Ltd. 
Table 2 Side-by-side comparison of partial sequences of three PR genes from Malus hupehensis with their respective PR genes from apple (Malus $\times$ domestica $\mathrm{cv}$.

\begin{tabular}{|c|c|c|c|c|c|c|}
\hline & MhPR1 & MdPR1 & MhPR5 & MdPR5 & MhPR8 & MdPR8 \\
\hline Identities & $155 / 160(96 \%)$ & & $151 / 153(98 \%)$ & & $111 / 112(99 \%)$ & \\
\hline Expect & $2 e-68$ & & $7 e-69$ & & $6 e-48$ & \\
\hline Gaps & $0 \%$ & & $0 \%$ & & $0 \%$ & \\
\hline GenBank & GU317941 & DQ318212 & GU317942 & DQ318213 & GU317943 & DQ318214 \\
\hline
\end{tabular}

\section{Results}

Identification of MhPR1, MhPR5, MhPR8 and MhTubulin from Malus hupehensis

In order to analyze the expression pattern of $P R$ genes in response to SA, MeJA and ACC in Malus hupehensis, the partial sequence of MhPR1, MhPR5 and MhPR8 were isolated from Malus hupehensis and the corresponding primes were set according to the sequence of PR genes isolated from apple (Malus $\times$ domestica $\mathrm{cv}$.) of which NCBI GenBank accession numbers were DQ318212, DQ318213 and DQ318214 respectively [19] (Table 2). The nucleotide sequences of MhPR1, MhPR5 and MhPR8 cloned from Malus hupehensis had 96\%, 98\% and 99\% identities with DQ318212, DQ318213 and DQ318214 respectively, and the corresponding sequences' numbers in GenBank were GU317941, GU317942 and GU317943.

Considered as the housekeeping gene, the MhTubulin gene was isolated from Malus hupehensis and has 99\% nucleotide sequence identities with TC31643 [20] and the nucleotide sequence of Malus hupehensis Tubulin gene was deposited in GenBank with corresponding accession number GU317944.

\section{Pathogenesis related (PR) genes were induced by SA, MeJA and ACC in leaves}

Taking the MhTubulin as housekeeping gene, semiquantitative RT-PCR analysis was performed with the RNA isolated from leaves of Malus hupehensis tissue culture seedlings following the treatments with SA, MeJA and ACC (Figure 1). MhPR5 and MhPR8 were basal expression in leaves, however, MhPR1 was not. Expression levels of $M h P R 1, M h P R 5$ and $M h P R 8$ were enhanced after inducing by SA, MeJA and ACC. During the first $48 \mathrm{~h}$, the expression of $M h P R 1$ was strongly induced at $4 \mathrm{~h}$ and gradually increased after sparing with SA and ACC, and was weakly induced at $4 \mathrm{~h}$ and $12 \mathrm{~h}$, and was strongly induced at $48 \mathrm{~h}$ in response to MeJA. MhPR5 was also strongly induced by SA at ACC at $48 \mathrm{~h}$ post-induced and by MeJA at $12 \mathrm{~h}$ post-induced. MhPR8 was delicately induced by SA, MeJA and ACC.

\section{Pathogenesis related genes were induced by SA, MeJA} and ACC in stems

The semi-quantitative RT-PCR demonstrated that all the three identified $P R$ genes were induced during $48 \mathrm{~h}$ following the treatments with SA, MeJA and ACC in stems (Figure 2). MhPR1, MhPR5 and MhPR8 were basal expression in stems. In contrast, for leaves, MhPR1 gene was intensively induced at $4 \mathrm{~h}$ postinduced by MeJA and ACC and at $12 \mathrm{~h}$ by SA. MhPR5 was delicate induced at $12 \mathrm{~h}$ and strongly induced at 48 $\mathrm{h}$ post-induced by SA, MeJA and ACC. Enhance expression of MhPR8 was found at $4 \mathrm{~h}$ after induced by SA, MeJA and ACC.

Pathogenesis related genes were induced by SA, MeJA and $A C C$ in roots

The semi-quantitative RT-PCR assay showed that MhPR1, MhPR5 and MhPR8 were induced by SA, MeJA and ACC in roots. Similar as in leaves, $M h P R 5$ and $M h P R 8$ were basal expression in roots, in which $M h P R 1$ was not. Enhanced expression of MhPR1 was conspicuous at $4 \mathrm{~h}$, and the expression level was gradually increasing after the treatment of SA, MeJA and ACC in roots. However, MhPR5 and MhPR8 were weakly induced during the first $48 \mathrm{~h}$ after processed with SA, MeJA and ACC (Figure 3).

\section{Discussion}

In 1970, PR proteins were founded in genotypes of tobacco infected with tobacco mosaic virus (TMV) [21]. After that, numbers of PR proteins had been reported as discovering in a wide variety of plant species [22], such as PR1 (unknown), PR2 ( $\beta$-1,3-glucanase), PR3 (chitinase type I, II, IV, V, VI, VII), PR5(osmotins), PR8 (chitinase type III )and $P R 10$ and so on[23,24]. In woody plants, the cDNA sequences of PR1 (GeneBank accession: AF195236, AF195237, FJ594483) and PR5 (thaumatin-like protein, GeneBank accession: FJ197337, FJ795347) were isolated from Pyrus. PR1 (PR1a, PR1b, $P R 1 c), P R-2, P R-5$ and $P R-8$ were identified as candidates in the responses to the attack by $E$. amylovora of apple based on the similarity to genes documented as involved in SAR in other plants. They were up-regulated in response to inoculation with the pathogen, E. amylovora[16]. In the study, the complete cDNA sequences of PR2 ( $\beta$-1,3-glucanase) and PR3 (chitinase) (date not shown) were cloned, as well as the partial cDNA sequence of $P R 1, P R 5$ and $P R 8$ from malus hupehensis. 


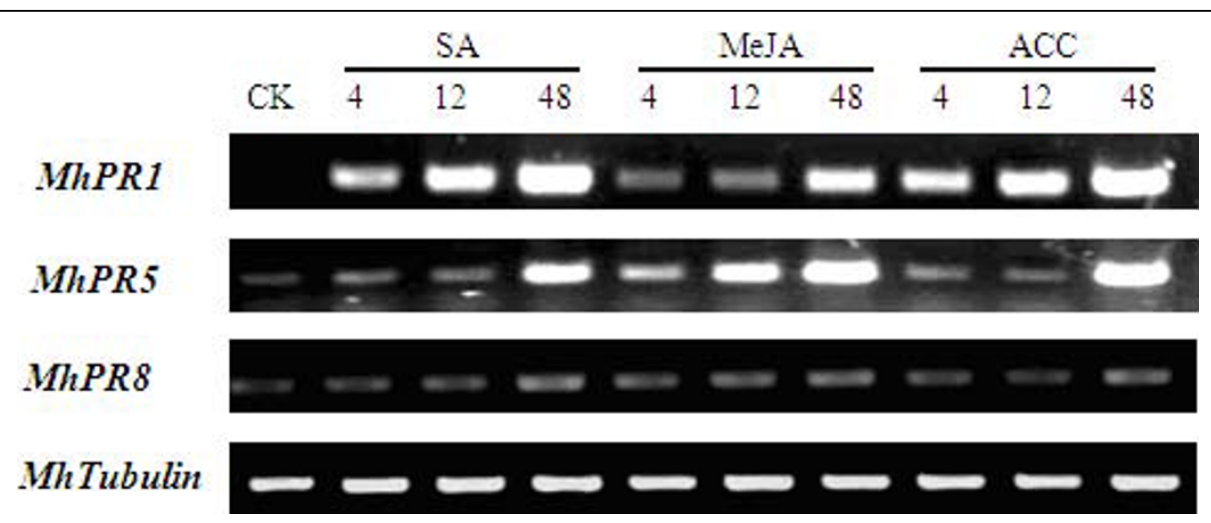

Figure 1 PR genes were induced by SA, MeJA and ACC in leaves. PR genes were induced by SA, MeJA and ACC in leaves using semiquantitative RT-PCR. MhTubulin transcript levels were used to normalize the samples. There were 25 cycles for MhTubulin and 35 for MhPR genes. $10 \mu \mathrm{l}$ RT-PCR production was assayed by electrophoresis on ethidium bromide stained 2.0\% agarose gels. Mh: Malus hupehensis. PR1: pathogenesis related protein 1; PR5: pathogenesis related protein 5; PR8: pathogenesis related protein 8.
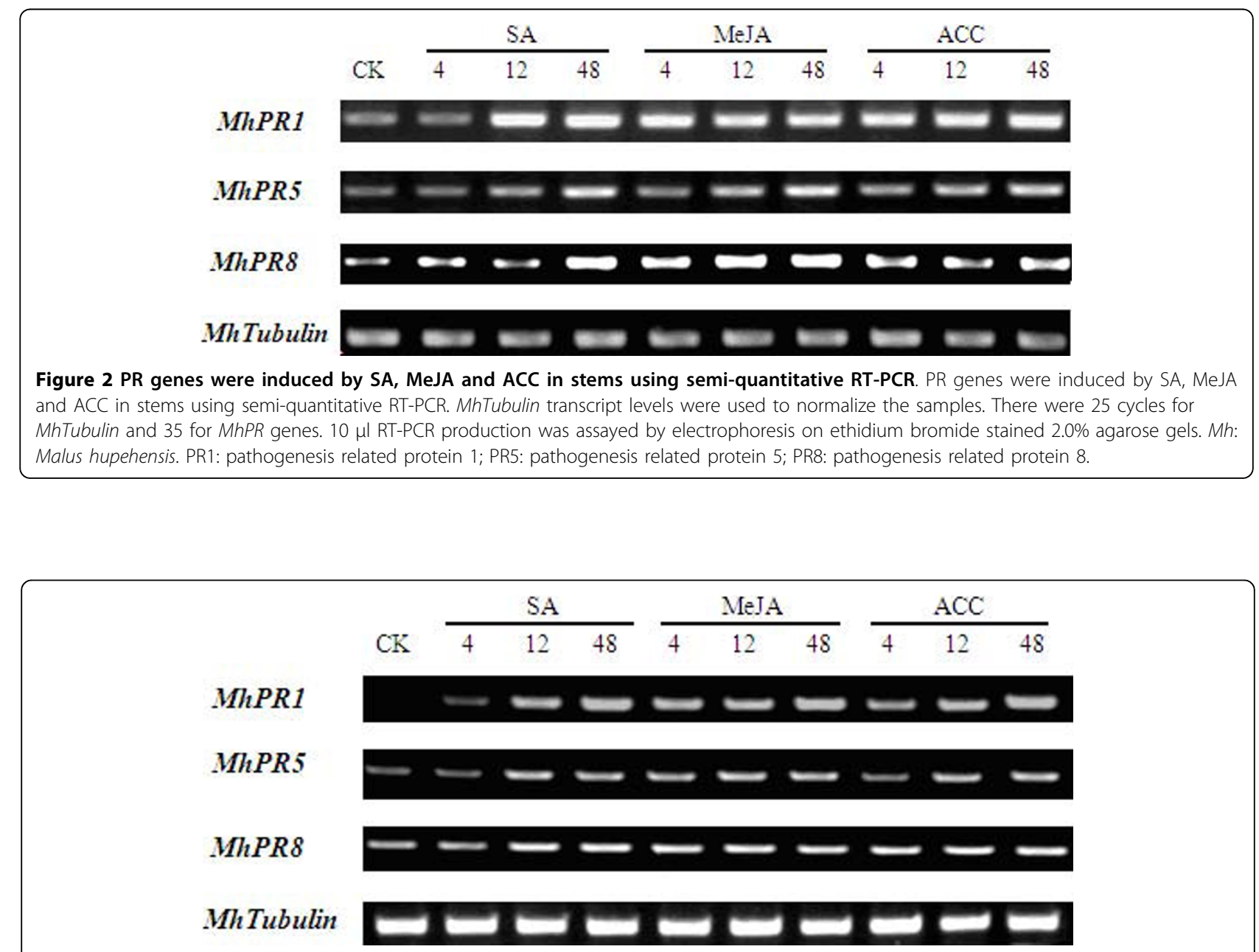

Figure 3 PR genes were induced by SA, MeJA and ACC in roots through semi-quantitative RT-PCR. PR genes were induced by SA, MeJA and ACC in roots using semi-quantitative RT-PCR. MhTubulin transcript levels were used to normalize the samples. There were 25 cycles for MhTubulin and 35 for MhPR genes. $10 \mu$ RT-PCR production was assayed by electrophoresis on ethidium bromide stained $2.0 \%$ agarose gels. Mh: Malus hupehensis. PR1: pathogenesis related protein 1; PR5: pathogenesis related protein 5; PR8: pathogenesis related protein 8. 
In Arabidopsis, PR1 is upregulated only by SA or INA (2, 6-dichloroisonicotinic acid), but is not induced by MeJA or ET [12]. In tobacco, PR1 is not only induced by SA but also recognized to be induced by a combination of ethylene and MeJA [25]. However, PR1 was not induced by MeJA or ET. PR1b gene was induced weakly by SA, but was strongly activated by exogenous JA in rice [26]. The expression of a member of the PR1 family was found to be constitutive and unaffected by treatments with BTH or salicylic acid in pear plants. The marker gene $P R 1$ is clearly not concerned first and foremost in the SAR response in pear [27]. In our study, it was surprised that the MhPR1 gene was not only strongly induced by SA but also intensively upregulated by MeJA and ACC in leaves, stems and roots in Malus hupehensis through semi-quantitative RT-PCR amplification. This conclusion suggested that MhPR1 might be a distinct pattern of expression differing from the reports previously for herbage plants such as arabidopsis, tobacco and rice. The result showed the MhPR1 gene could be regarded as a marker gene in the SAR response in Malus hupehensis.

In tobacco, PR5 gene is regulated by $\mathrm{SA}, \mathrm{MeJA}, \mathrm{ET}$, abscisic acid (ABA) and so on [25,28-30]. The combination of ET and MeJA induced both mRNA and protein of PR5 to accumulate in tobacco [25]. The expression of $P R 5$ was in response to SA and INA in arabidopsis. MhPR5 gene was strongly induced by the treatment with SA, MeJA and ACC in leaves, and weakly upregulated in stems and roots. The same as MhPR1, MhPR5 gene was regarded as a marker gene in the SAR response in Malus hupehensis. Expression pattern of MhPR8 was different in all kinds of tissues in the study. $M h P R 8$ was strongly induced in stems, weakly induced in leaves and roots with SA, MeJA and ACC.

PR genes have a distinctive pattern of expression in Malus hupehensis in contrast with the Arabidopsis, tobacco and rice. It was surprised that MhPR1, MhPR5 and MhPR8 expression enhanced in response to SA, MeJA and ACC in leaves, stems and roots. Thus, the results indicated that more than one single signal pathway regulated one member of the PR genes together and a signal pathway could regulate some members of the PR genes at the same time. Signal pathways of resistant to pathogen of woody fruit trees are different from herbage plants. The further study on the SA-, JA-, and ET-dependent signaling pathways response to pathogen in woody plants should be necessary.

\section{Conclusions}

The expression of MhPR1, MhPR5 and MhPR 8 were enhanced during the first 48 hours after induced with SA, MeJA and ACC in leaves, stems and roots. Thus, $M h P R 1, M h P R 5$ and MhPR8 genes were regarded as the marker genes in the SAR response in Malus hupehensis. In contrast with herbage plants, $P R$ genes have a distinctive expression pattern in response to SA, MeJA and ACC in woody plants. It was feasible that the expression pattern of PR genes in woody plants attacked by pathogen could be different with the herbage plants. The woody plants could have specific signal pathway in response to pathogen.

\section{Acknowledgements}

We gratefully acknowledge the support of this work from the National Technological Department Fatal Transgenic 863 Item in China (2008AA10Z157) and Jiangsu Province Technological Support Plan (BE2008316).

\section{Author details}

'College of Horticulture, Nanjing Agricultural University, 1 Weigang, Nanjing, Jiangsu, China. ${ }^{2}$ Liaoning Agricultural Vocation-Technical College, Yingkou, Liaoning, China.

\section{Authors' contributions}

$J Z$ carried out all the experiments, prepared the figures and drafted the manuscript. $X D, D L$ and $X C$ performed the sample preparation and participated in tables drawing. $\mathrm{KX}$ and $\mathrm{QW}$ assisted in manuscript revising and provided helpful discussions. SQ and ZZ were responsible for experimental design and revised and polished the manuscript. All authors have read and approved the final manuscript.

\section{Competing interests}

The authors declare that they have no competing interests.

Received: 12 February 2010 Accepted: 27 July 2010

Published: 27 July 2010

\section{References}

1. Poelman EH, Broekgaarden C, Van Loon JJA, Dicke M: Early season herbivore differentially affects plant defence responses to subsequently colonizing herbivores and their abundance in the field. Molecular Ecology 2008, 17:3352-3365.

2. Pieterse CMJ, Van Loon LC: Salicylic acid-independent plant defence pathways. Trends in Plant Science 1999, 4:52-57.

3. Van Wees SCM, de Swart EAM, van Pelt JA, van Loon LC, Pieterse CMJ: Enhancement of induced disease resistance by simultaneous activation of salicylate- and jasmonate-dependent defense pathways in Arabidopsis thaliana. Proc Natl Acad Sci USA 2000, 97:8711-8716.

4. Thaler JS, Owen B, Higgins VJ: The role of the jasmonate response in plant susceptibility to diverse pathogens with a range of lifestyles. Plant Physiology 2004, 135:530-538.

5. Von Dahl CC, Baldwin IT: Deciphering the role of ethylene in plant herbivore interactions. Journal of Plant Growth Regulation 2007, 26:201-209.

6. Leon-Reyes A, Spoel SH, De Lange ES, Abe H, Kobayashi M, Tsuda S, Millenaar FF, Welschen RAM, Ritsema T, Pieterse CMJ: Ethylene modulates the role of NONEXPRESSOR OF PATHOGENESIS-RELATED GENES1 in cross talk between salicylate and jasmonate signaling. Plant Physiology 2009, 149:1797-1809.

7. Koornneef A, Pieterse CMJ: Cross-talk in defense signaling. Plant Physiology 2008, 146:839-844

8. Spoel SH, Dong X: Making sense of hormone crosstalk during plant immune responses. Cell Host Microbe 2008, 3:348-351.

9. Thomma BPHJ, Eggermont K, Penninckx IAMA, Mauch-Mani B, Vogelsang R, Cammue BPA, Broekaert WF: Separate jasmonate-dependent and salicylate-dependent defense-response pathways in Arabidopsis are essential for resistance to distinct microbial pathogens. Proc Natl Acad Sci USA 1998, 95(25):15107-15111.

10. Ton J, Van Pelt JA, Van Loon LC, Pieterse CMJ: Differential effectiveness of salicylate-dependent and jasmonate/ethylene-dependent induced 
resistance in Arabidopsis. Molecular Plant-Microbe Interactions 2002, 15(1):27-34

11. van Loon LC, Pierpoint WS, Boller T, Conejero V: Recommendations for Naming Plant Pathogenesis-Related Proteins. Plant Molecular Biology Reporter 1994, 12(3):245-264.

12. Durrant WE, Dong X: Systemic Acquired Resistance. Annual Review of Phytopathology 2004, 42(1):185-209.

13. Tornero P, Gadea J, Conejero V, Vera P: Two PR-1 Genes from Tomato Are Differentially Regulated and Reveal a Novel Mode of Expression for a Pathogenesis-Related Gene During the Hypersensitive Response and Development. Molecular Plant-Microbe Interaction 1997, 10(5):624-634.

14. Gaffney T, Friedrich L, Vernooij B, Negrotto D, Nye G, Uknes S, Ward E, Kessmann H, Ryals J: Requirement of Salicylic Acid for the Induction of Systemic Acquired Resistance. Science 1993, 261(5122):754-756.

15. Lawton KA, Beck J, Potter S, Ward E, Ryals J: Regulation of cucumber class III chitinase gene expression. Mol Plant Microbe Interact 1994, 7(1):48-57.

16. Bonasera1 JM, Kim JF, Beer SV: PR genes of apple: identification and expression in response to elicitors and inoculation with Erwinia amylovora. BMC Plant Biology 2006, 6:23.

17. Cai BH, Zhang JY, Gao ZH, Qu SC, Tong ZG, Mi L, Qiao YS, Zhang Z: An improved method for isolation of total RNA from the leaves of Fragaria spp. Journal of Jiangsu Agriculture Science 2008, 24(6):875-877.

18. BLASTn program. [http://blast.ncbi.nlm.nih.gov/Blast.cgi?PROGRAM=blastn\& BLAST_PROGRAMS=megaBlast\&PAGE_TYPE=BlastSearch\&SHOW_DEFAULTS $=$ on\&LINK_LOC=blasthome)].

19. NCBI: National Center for Biotechnology Information. [http://www.ncbi. nIm.nih.gov].

20. The DFCI Malus $\times$ domestica Gene Index (MdGI). [http://compbio.dfci. harvard.edu/cgi-bin/tgi/tc_report.pl?tc=TC31643\&species=Apple].

21. Van Loon LC, Van Kammen A: Polyacrylamide discelectrophoresis of the soluble leaf proteins from Nicotiana tabacumvar. 'Samsun' and 'Samsun NN: II. Changes in protein constitution after infection with tobacco mosaic virus. Virology 1970, 40(2):190-211.

22. Cutt JR, Klessig DF: Pathogenesis-related proteins. In Genes Involved in Plant Defense (New York Springer-Verlag)Bollerand T, Meins F 1992, 209-243.

23. Van Loon IC, Van Strein EA: The families of pathogenesis-related proteins, their activities, and comparative analysis of PR-1 type proteins. Physiological and Molecular Plant Pathology 1999, 55:85-97.

24. Muthukrishnan S, Liang GH, Trick HN, Bikram SG: Pathogenesis-related proteins and their genes in cereals. Plant Cell Tissue and Organ Culture 2001, 64:93-114.

25. Xu Y, Chang PFL, Liu D, Narasimhan ML, Raghothama KG, Hasegawa PM, Bressan RA: Plant Defense Genes Are Synergistically Induced by Ethylene and Methyl Jasmonate. The Plant Cell 1994, 6:1077-1085.

26. Mei CS, Qi M, Sheng GY, Yinong Yang YN: Inducible Overexpression of a Rice Allene Oxide Synthase Gene Increases the Endogenous Jasmonic Acid Level, $P R$ Gene Expression, and Host Resistance to Fungal Infection. Molecular Plant-Microbe Interactions 2006, 19(10):1127-1137.

27. Sparla F, Rotino L, Valgimigli MC, Pupillo P, Trost P: Systemic resistance induced by benzothiadiazole in pear inoculated with the agent of fire blight (Erwinia amylovora). Scientia Horticulturae 2004, 101:269-279.

28. Singh NK, Nelson DE, Kuhn D, Hasegawa PM, Bressan RA: Molecular cloning of osmotin and regulation of its expression by $A B A$ and adaptation to low water potential. Plant Physiology 1989, 90:1096-1101.

29. Brederode FT, Linthorst HJM, Bol JF: Differential induction of acquired resistance and PR gene expression in tobacco by vira1 infection, ethephon treatment, UV light and wounding. Plant Molecular Biology 1991, 17:1117-1125.

30. Stintzl A, Heitz T, Kauffmann S, Legrand M, Fritig B: Identification of a basic pathogenesis-related thaumatin-like protein of virus-infected tobacco as osmotin. Physiological and Molecular Plant Pathology 1991, 38:137-146.

doi:10.1186/1756-0500-3-208

Cite this article as: Zhang et al.: Expression of pathogenesis related genes in response to salicylic acid, methyl jasmonate and 1aminocyclopropane-1-carboxylic acid in Malus hupehensis (Pamp.) Rehd. BMC Research Notes 2010 3:208.

\section{Submit your next manuscript to BioMed Central and take full advantage of:}

- Convenient online submission

- Thorough peer review

- No space constraints or color figure charges

- Immediate publication on acceptance

- Inclusion in PubMed, CAS, Scopus and Google Scholar

- Research which is freely available for redistribution

Submit your manuscript at www.biomedcentral.com/submit 